PENANGGUNG JAWAB

Dekan Fakultas Ilmu Tarbiyah dan Keguruan

REVIEWER

Ani Cahyadi

Universitas Islam Negeri Antasari Banjarmasin, Indonesia

Imam Rofiki

Universitas Islam Negeri Maulana Malik Ibrahim Malang, Indonesia

Nuril Mufidah

Universitas Islam Negeri Maulana Malik Ibrahim Malang, Indonesia

Nuri Wuryandani

Universitas Negeri Yogyakarta, Indonesia

Muhammad Walid

Universitas Islam Negeri Maulana Malik Ibrahim Malang, Indonesia

Wahid Murni

Universitas Islam Negeri Maulana Malik Ibrahim Malang, Indonesia

EDITOR IN CHIEF

M. Irfan Islamy

Universitas Islam Negeri Maulana Malik Ibrahim Malang, Indonesia

SECTION EDITOR

Abdul Fattah

Universitas Islam Negeri Maulana Malik Ibrahim Malang, Indonesia

Galih Puji Mulyanto

Universitas Islam Negeri Maulana Malik Ibrahim Malang, Indonesia

Dewi Nur Suci

Sekolah Tinggi Agama Islam Kediri, Indonesia

Dwi Sulistiani

Universitas Islam Negeri Maulana Malik Ibrahim Malang, Indonesia

LAYOUT EDITOR

Rendi Setyo Marandi

Universitas Islam Negeri Maulana Malik Ibrahim Malang, Indonesia 
ii | P a g e

PEDOMAN TRANSLITERASI

\begin{tabular}{|c|c|c|c|}
\hline Arab & Latin & Arab & Latin \\
\hline 1 & $\mathrm{a}$ & ض & $\mathrm{dh}$ \\
\hline ب & b & b & th \\
\hline ت & $\mathrm{t}$ & ظ & zh \\
\hline ث & ts & $\varepsilon$ & I \\
\hline ج & $\mathrm{j}$ & $\dot{\varepsilon}$ & gh \\
\hline$\tau$ & h & ف & $\mathrm{f}$ \\
\hline$\dot{\tau}$ & kh & ق & $\mathrm{q}$ \\
\hline د & d & ك ك & $\mathrm{k}$ \\
\hline ذ & $\mathrm{dz}$ & J & 1 \\
\hline J & $r$ & م & $\mathrm{m}$ \\
\hline j & Z & ن & $\mathrm{n}$ \\
\hline س & $\mathrm{S}$ & 9 & W \\
\hline ش & sy & هـ & $\mathrm{h}$ \\
\hline ص & sh & ى & $\mathrm{y}$ \\
\hline
\end{tabular}


DAFTAR ISI

i

PENANGGUNG JAWAB

i

REVIEWER

i

EDITOR IN CHIEF

i

SECTION EDITOR

i

LAYOUT EDITOR

ii

PEDOMAN TRANSLITERASI

iii

DAFTAR ISI

01-12

Pembelajaran Bahasa Arab di MIN 13 Kabupaten Banjar Kalimantan Selatan

Mahmudah

Universitas Islam Negeri Antasari Banjarmasin, Indonesia

13-23

Keefektifan Model Make A Match dalam Pembelajaran Matematika Siswa Kelas VI

Sekolah Dasar di Kecamatan Marioriwawo

Andi Kaharuddin

Universitas Lakidende Unaaha, Indonesia

24-39

Konsepsi Penerapan Keterampilan Proses Sains (KPS) dan Sikap Ilmiah Dalam Desain Pengembangan Modul Panduan Eksperimen Ipa SD/MI

Ida Fiteriani ${ }^{1}$ dan Baharuddin ${ }^{2}$

1,2Universitas Islam Negeri Raden Intan Lampung, Indonesia

40-45

Pengembangan Multimedia Pembelajaran Interaktif Materi Pokok Sistem Tata Surya Untuk Siswa Kelas VI SD

Vannisa Aviana Melindaㄹ, Dimas Sambung'2, Dian Eka Aprilia Fitria Ningrum³ ${ }^{3}$ Imroatul Hayyu Erfantinni ${ }^{4}$, Roiyan One Febriani ${ }^{5}$

1,2,3,4,5Universitas Islam Negeri Antasari Banjarmasin Indonesia, Indonesia

46-52

Pengembangan Media Pembelajaran Pop-Up Berbasis Sains Kelompok B RA Raden Fatah Podorejo

Dessy Putri Wahyuningtyas ${ }^{1}$, Faizatun Na'fiah

1,2Universitas Islam Negeri Maulana Malik Ibrahim Malang, Indonesia

PEDOMAN PENULISAN

UCAPAN TERIMAKASIH

Vol. 11 No. 1, Desember 2018

Madrasah homepage: http://ejournal.uin-malang.ac.id/index.php/madrasah/index 


\title{
PENGEMBANGAN MEDIA PEMEBELAJARAN POP-UP BERBASIS SAINS PADA KELOMPOK B RA RADEN FATAH PODOREJO
}

\author{
Dessy Putri Wahyuningtyas ${ }^{1}$ dan Faizatun Nafi' ah $^{2}$ \\ Universitas Islam Negeri Maulana Malik Ibrahim Malang \\ 1dessyputriwahyuningtyas@gmail.com,2faizaannafi@gmail.com
}

DOI: $10.18860 /$ madrasah.v11i1.6166

Abstrak. Pengembangan media pembelajaran sains berbasis pop-up adalah sarana untuk membantu anak-anak memahami dan meningkatkan kemampuan kognitif anak-anak dalam sains. Tujuan penelitian ini adalah: (1) mengembangkan pembelajaran sains melalui media pop-up, (2) untuk mengetahui penerapan pembelajaran sains melalui media pop-up, (3) untuk mengetahui tentang belajar pemahaman siswa terhadap sains setelah menggunakan pop-up media. Penelitian ini menggunakan metode penelitian dan pengembangan (R D \&). Penelitian ini mengacu pada pengembangan model Dick and Carey. Prosedur untuk mengembangkan media pembelajaran berbasis pop-up menggunakan beberapa langkah, sebagai berikut: analisis kebutuhan, desain produk, desain dan melakukan evaluasi formatif (pengujian untuk individu, kelompok Dewan kecil, uji coba lapangan), revisi. Hasil validasi konten mencapai tingkat validitas dari $82 \%$, desain validasi media mencapai $91 \%$ dan validitas guru kelas mencapai $90 \%$. Ini menunjukkan bahwa media pembelajaran layak dan ini dapat digunakan dalam proses pembelajaran. Kemampuan kognitif anak-anak yang menggunakan media pop-up belajar meningkat, hal ini dapat dilihat dari nilai persentase rata-rata sebelum tes dari 61,1 menjadi 88,3. Jadi, dengan menggunakan anak-anak pop-up media lebih memahami tentang pembelajaran sains.

Kata Kunci. Pembelajaran Sains; Media Pop-Up; Pendidikan Anak Usia Dini

Abstract. Learning media development pop-up-based science is a means to help children understand and improve the cognitive ability of children in science. The purpose of this research is: (1) to develop learning science through the media pop-up, (2) to know the application of learning science through the media pop-up, (3) to find out about learning student understanding of science after using the media pop-up. This research uses the methods of research and development (R D \&). This study refers to the development of the model of the Dick and Carey. Procedures for developing instructional media pop-up-based science uses several steps, as follows: needs analysis, product design, design and conduct formative evaluation (testing for individuals, the Council groups small, field trial), revision. The results of the validation of the content reaches the level of the validity of the $82 \%$, design validation media reaches $91 \%$ and the validity of the classroom teacher reached $90 \%$. This suggests that the learning media worthy and this can be used in the learning process. The cognitive ability of children who use the media pop-up learning increasing, it can be seen from the average percentage value before tests from 61.1 be 88.3 . So, by using the pop-up media children understand more about the learning of science

\begin{tabular}{ll|l}
\hline \multicolumn{2}{l}{ Keywords. Learning Science; The Pop-Up Media; Early Childhood Education } \\
\hline Received : 16 September 2018 & Approved : 30 Desember 2018 \\
Reviesed $: 24$ Desember 2018 & Published :31 Desember 2018 \\
\hline
\end{tabular}

Copyright (C) Madrasah Jurnal Pendidikan dan Pembelajaran Dasar. All Right Reserved.

This is an open access article under the CC BY-NC-ND license

(http://creativecommons.org/licenses/by-nc-nd/4.0/).

Correspondence Address: dessyputriwahyuningtyas@gmail.com 


\section{MADRASAH}

Jurnal Pendidikan dan Pembelajaran Dasar

p ISSN: 1979-5599 | e ISSN: 2502-194X

P a ge

\section{A. PENDAHULUAN}

Pendidikan anak usia dini adalah upaya pembinaan yang ditujukan kepada anak sejak lahir sampai usia enam tahun yang dilakukan melalui pemberian rangsangan pendidikan untuk membantu pertumbuhan dan perkembangan agar memiliki kesiapan dalam memasuki pendidikan lebih lanjut. Tidak hanya calistung yang anak pelajari di Sekolah, kemandirian dalam aktivitas sehari-hari juga pembelajaran sains sederhana juga harus mereka pahami. Maka dari itu, pembelajaran sains dengan pendekatan bermain sambil belajar dapat meningkatkan hasil belajar kognisi, afeksi, dan psikomotorik, serta menumbuhkan kemampuan berpikir siswa TK, karena dalam pembelajaran sains anak akan mengembangkan kemampuan memecahkan masalah yang dihadapinya melalui proses ilmiah (Yulianti, 2010). Pengembangan pembelajaran sains melalui bermain juga dapat mengembangkan pemahaman anak tentang alam beserta isinya. Proses pembelajaran sains dengan bermain akan memudahkan anak untuk memahami informasi yang telah disampaikan.

Standar kompetensi yang diharapkan dari anak Taman Kanak-Kanak yang berkaitan dengan sains adalah memilih, memadukan dan menerapkan konsep dan teknik, pola, struktur dan hubungan, mencari dan menerapkan tegnologi informasi yang diperlukan, memahami dunia fisik, makhluk hidup dan tegnologi serta menggunakan pengetahuan dan keterampilan dan nilai-nilai untuk mengambil keputusan (Dewi, 2012). Hasil belajar yang dicapai merupakan cerminan kemampuan anak dari suatu tahapan pengalaman belajar dalam satu kompetensi dasar. Sehingga peran seorang pendidik harus mampu memfasilitasi akivitas anak dan sebagai transfer ilmu pengetahuan (Padmowihardjo, 2014).

Pembelajaran sains pada generasi penerus harus terus menerus dilakukan mulai dari usia dini hingga dewasa. Lemahnya proses pembelajaran sains di tingkat TK/RA adalah salah satu masalah yang sering dihadapi dalam dunia pendidikan. Kemungkinan penyebabnya adalah penyampaian materi sains tanpa menggunakan media pembelajaran dalam proses pembelajaran. Seperti pembelajaran di RA Raden Fatah Podorejo yang sampai saat ini masih sering meggunakan metode ceramah dan tidak menggunakan media pembelajaran yang dapat memudahkan anak untuk memahami materi.

Salah satu perkembangan anak yang tidak boleh terlewatkan adalah perkembangan kognitif. Perkembangan kognitif anak Taman Kanak-kanak dan Raudharul Athfal atau anak dalam fase praoperasonal dapat dikenali dengan kemampuan untuk melakukan kegiatan representasi mental, yaitu kemampuan anak untuk menghadirkan benda, objek, atau orang dan peristiwa secara mental (Yulianti, 2010). Anak sudah mulai bisa membayangkan di dalam pikirannnya walaupun dalam kenyataannya anak tidak melihat secara langsung. Kemampuan tersebut disebut sebagai kemampuan berfikir simbolis.

Sains memiliki cakupan materi yang mempunyai kegiatan menelusuri, mengamati, dan melakukan percobaan, proses tersebut akan membuat suasana belajar yang membawa anak ke dalam proses ilmiah. Anak akan memahami pengetahuan melalui objek yang ada dilingkungannya (Yulianti, 2010). Ketika anak berinteraksi dengan lingkungan atau benda disekitarnya, kemampuan kognitif anak dalam memahami fenomena yang terjadi akan meningkat dengan cara mengeksplor secara langsung. Sehingga salah satu cara pendidik untuk memudahkan peserta didik menyerap informasi atau materi yang disampaikan dengan menggunakan media.

Penggunaan media perlu karena untuk menunjang pembelajaran di kelas. Melalui media anak mampu mengamati, menyentuh, mencium dan mendengar objek secara langsung. Pembuatan media pembelajaran dengan baik, efisien dan efektif, memerlukan kemampuan serta keterampilan, karena membuat media pembelajaran harus sesuai dengan usia anak sehingga anak tidak kesulitan dalam memahami materi dan menyerap informasi yang telah disampaikan (Yulianti, 2010). 
Media pop-up menjadi alternatif media pembelajaran tiga dimensi yang memiliki keunggulan bila dibandingkan dengan gambar yang hanya dua dimensi (Budiarti, 2017). Media pop-up sangat membantu untuk mewujudkan realitas yang tidak saja dapat dilihat, tetapi juga dapat diraba. Dengan penggunaan media dalam pembelajaran mampu meningkatkan ketertarikan dan rasa ingin tahu anak dengan pengetahuan-pengetahuan baru.

Berdasarkan uraian di atas maka diperlukan adanya pengembangan media pembelajaran pop-up berbasis sains pada kelompok B RA Raden Fatah Podorejo. Penelitian ini dianggap penting dilakukan karena dapat menghasilkan media pembelajaran alternatif yang dapat dijadikan solusi dari permasalahan yang terjadi.

\section{B. KAJIAN PUSTAKA}

1. Pengembangan

Suatu pengembangan bermaksud untuk meningkatkan dan mencapai tujuan tertentu. Dalam dunia pendidikan, sangat penting bahwa ada pengembangan, karena dengan pengembangan yang dilakukan akan meningkatkan dan meningkatkan kualitas proses pembelajaran. Pendekatan tematik adalah salah satu pendekatan pembelajaran yang digunakan di taman kanak-kanak dan Raudhatul Athfal (TK / RA). Guru dalam pendekatan tematik ini harus kreatif dalam membuat media pembelajaran (ilustrasi dan contoh menarik) dan mampu menciptakan kelas yang menyenangkan dan hidup untuk menciptakan kekompakan dalam membentuk pemahaman dan kompetensi antara guru dan siswa (Alma, 2009; Mulyasa, 2007; Suprihatiningrum, 2013).

2. Pembelajaran Sains Pada Anak Usia Dini

Ilmu pengetahuan anak usia dini adalah bagaimana memahami ilmu pengetahuan berdasarkan perspektif anak-anak. sains yang mencakup pencarian, pengamatan, dan percobaan, sangat penting bagi anak-anak TK untuk berpartisipasi dalam proses ilmiah, karena keterampilan yang mereka dapatkan dapat dibawa ke perkembangan lain dan akan bermanfaat sepanjang hidup mereka.

Ilmu pengetahuan untuk anak usia dini adalah segala sesuatu yang menakjubkan, sesuatu yang ditemukan dan dianggap menarik dan memberikan pengetahuan atau merangsang untuk mengetahui dan menyelidiki. Untuk anak-anak TK objek sains mencakup objek di sekitar anak dan objek yang sering menjadi perhatian anak. Air, udara, bunyi, api, tanah, tanaman, hewan, dan diri mereka sendiri adalah objek sains yang sering menjadi perhatian anak-anak. Berbagai gejala alami seperti hujan, angin, kilat, api, binatang yang berkembang biak, tanaman yang juga menarik perhatian anak-anak.

Beberapa bahan sains yang cocok untuk anak-anak TK adalah topik sains yang memberikan pengalaman langsung kepada anak-anak, bukan belajar konsep-konsep ilmiah abstrak. Selain itu pembelajaran sains harus mengembangkan kemampuan untuk mengamati, mengklarifikasi, mengukur dengan menggunakan angka dan mengidentifikasi hubungan sebab akibat.

\section{Karakteristik Anak Usia Dini}

Siswa di taman kanak-kanak dan Raudhatul Athfal adalah anak-anak prasekolah yang perilaku alaminya dapat diidentifikasi berdasarkan karakteristik berikut: Senang menjelajahi lingkungan; Mengamati dan memegang segala sesuatu, eksploratif ekspansif dan berlebihan; Keingintahuannya yang besar, suka mengajukan pertanyaan tanpa henti; Nikmati petualangan, selalu ingin mendapatkan pengalaman baru; Senang bereksperimen, membongkar, dan mencoba segalanya; Jarang merasa bosan, ada beberapa hal yang ingin Anda lakukan; dan juga memiliki imajinasi yang tinggi (Yus, 2011).

Perkembangan kognisi anak-anak di taman kanak-kanak dan Raudhatul Athfal atau anak-anak pada fase praoperasi dapat diidentifikasi dengan kemampuan untuk melakukan kegiatan representasi mental, yaitu kemampuan anak untuk menyajikan objek, objek, atau 


\section{MADRASAH}

Jurnal Pendidikan dan Pembelajaran Dasar

p ISSN: 1979-5599 | e ISSN: 2502-194X

P a g e

orang dan peristiwa mental (Ward, 2010). Ini berarti bahwa anak sudah mulai dapat membayangkan dalam benaknya walaupun pada kenyataannya anak tidak melihatnya secara langsung. Kemampuan ini disebut kemampuan berpikir simbolis. Ketika anak itu bermain, pikiran simbolis pasti akan ada.

Pemikiran simbolik adalah salah satu karakteristik anak-anak pada fase praoperasi, ini ditandai dengan anak-anak suka meniru perilaku yang dilakukan orang lain, hewan atau kejadian di sekitarnya. Sebelum anak meniru, anak akan melakukan pengamatan objek. Pada tahap Praoperasi dapat disebut sebagai rentang anak usia dini. Kehidupan awal adalah periode yang singkat, tetapi sangat penting bagi kehidupan seseorang. Oleh karena itu, pada tahap ini semua potensi anak perlu didorong sehingga akan berkembang secara optimal.

4. Media Pembelajaran

Media pembelajaran adalah alat pendidikan yang dapat digunakan sebagai perantara dalam proses pembelajaran untuk meningkatkan efektivitas dan efisiensi dalam mencapai tujuan pembelajaran. Dalam arti yang lebih luas, media pembelajaran adalah alat, metode, dan teknik yang digunakan untuk memperlancar komunikasi dan interaksi antara guru dan peserta didik dalam proses pembelajaran di kelas.

Media pembelajaran memiliki pengaruh terbesar pada indera dan dapat lebih menjamin pemahaman, orang yang mendengarkan sendiri tidak memiliki tingkat pemahaman yang sama dan durasi dari apa yang mereka pahami dibandingkan dengan mereka yang melihat atau melihat dan mendengarnya.

Pengembangan media pembelajaran harus diupayakan untuk memanfaatkan keunggulan yang dimiliki oleh media dan berusaha menghindari hambatan yang mungkin timbul dalam proses pembelajaran. Media pembelajaran digunakan untuk meningkatkan atau meningkatkan kualitas proses kegiatan belajar mengajar yang akan dilakukan di sekolah.

Setelah mengetahui tujuan, manfaat dan fungsi media pembelajaran, langkah selanjutnya adalah menentukan pemilihan media yang akan digunakan dalam proses pembelajaran di kelas. Pertimbangan media yang akan digunakan dalam pembelajaran adalah pertimbangan utama. Hubungan antara media pembelajaran dengan tujuan, bahan, metode dan kondisi pembelajaran, harus menjadi perhatian dan pertimbangan guru untuk memilih dan menggunakan media dalam proses pembelajaran di kelas, sehingga media yang digunakan lebih efektif dan efisien untuk mencapai tujuan pembelajaran (Aisyah, 2008; Sanaky, 2009). Media untuk anak-anak umumnya berupa bahan dan peralatan permainan.

Buku pop-up adalah buku yang memiliki bagian bergerak atau memiliki elemen 3 dimensi. Sekilas pop-up hampir sama dengan origami di mana kedua seni ini adalah teknik melipat kertas. Meski begitu origami lebih fokus pada pembuatan objek atau objek, sedangkan pop-up lebih cenderung membuat kertas mekanis yang dapat membuat gambar terlihat lebih berbeda, baik dari segi dimensi, perubahan bentuk sehingga mereka dapat bergerak sealami mungkin.

Jadi, jika dalam dunia pendidikan menggunakan media pembelajaran tiga dimensi tentunya dapat menarik perhatian siswa untuk mengetahuinya. Pop-up dapat memberikan visualisasi cerita yang lebih menarik. Mulai dari tampilan gambar yang terlihat lebih dimensional, gambar yang bisa bergerak ketika halaman dibuka, atau bagian yang bergeser, bagian yang bisa berubah bentuk, memiliki tekstur seperti objek asli bahkan ada yang bisa bersuara. Hal-hal seperti ini membuat cerita lebih menyenangkan dan menarik untuk dinikmati.

Pop-Up memiliki kemampuan untuk memperkuat kesan yang ingin Anda sampaikan dalam sebuah cerita sehingga bisa dirasakan lebih banyak. Tampilan visual yang lebih berdimensi membuat cerita terasa lebih nyata plus kejutan yang diberikan di setiap halaman. 
Gambar dapat tiba-tiba muncul dari belakang halaman atau bangunan dapat berdiri dengan anggun di tengah halaman dengan memvisualisasikannya, kesan yang ingin Anda tampilkan dapat disampaikan lebih banyak.

\section{METODE PENELITIAN}

Desain yang digunakan dalam penelitian ini adalah Penelitian dan Pengembangan (Litbang). Melalui pendekatan kuantitatif, peneliti mengambil jarak dari yang dipelajari, dengan mengambil jarak itu akan mendapatkan tingkat obyektivitas yang tinggi. Dalam penelitian pengembangan media pembelajaran ini, mengacu pada model pengembangan Borg \& Gall (1983), dalam urutan berikut: 1) Penelitian dan pengumpulan informasi awal, 2) Perencanaan, 3) Pengembangan format produk awal, 4) Uji coba awal ,5) Revisi produk, 6) Uji coba lapangan, 7) Revisi produk, 8) Uji implementasi lapangan, 9) Revisi produk akhir, 10) Penyebaran dan implementasi.

\section{HASIL DAN PEMBAHASAN}

Deskripsi media pembelajaran pop-up berbasis sains dalam hal isi media pembelajaran, yaitu:

1. Ayo kenali, di halaman ini anak-anak diajak mengamati gambar berbagai hewan ternak, di halaman ini juga tersedia kartu nama hewan. Kemudian anak diminta untuk mencocokkan kartu kata binatang sesuai dengan gambar binatang.

2. Mari kita hitung, di halaman ini ada berbagai jenis hewan ternak dengan nomor yang berbeda, juga tersedia kartu 1-10 kata. Kemudian anak diminta untuk menambahkan hewan dan mencocokkannya sesuai dengan kartu 1-10 kata.

3. Mari kita klasifikasikan, di halaman ini ada gambar kambing, ayam dan ikan, dilengkapi dengan kartu kata untuk gambar binatang dan kantong untuk dikelompokkan. Kemudian anak diminta untuk mengelompokkan hewan sesuai dengan instruksi.

4. Mari kita baca, ada kalimat tentang ternak yang hidup di darat dan ternak yang hidup di air, lalu anak membaca kalimat itu.

5. Menyusun puzzle, di halaman ini disajikan permainan puzzle untuk anak-anak mainkan.

Beberapa hal yang perlu diperhatikan dalam membuat media pembelajaran pop-up berbasis sains adalah sebagai berikut:

1. Kertas yang digunakan oleh Kertas Seni 190 untuk kartu kata, Kertas Seni 230 untuk basis buku / halaman dan Kertas Seni 260 untuk pop-up / gambar yang dihasilkan.

2. Penggunaan layout di media pembelajaran dalam bentuk lulusan yang menarik.

3. Gambar yang digunakan menarik.

4. Media

5. pembelajaran pop-up berbasis sains dibuat di atas kertas A4 bersampul keras.

Media pembelajaran pop-up berbasis sains ini diharapkan dapat meningkatkan pemahaman anak-anak dan kemampuan kognitif anak-anak untuk meningkat seperti yang diharapkan. Hasil validasi dari beberapa mata pelajaran telah dikonversi pada skala persentase berdasarkan tingkat validitas serta pedoman untuk merevisi media pembelajaran yang dikembangkan dengan tingkat pencapaian sebagai berikut:

1. Validasi konten materi. Berdasarkan hasil perhitungan, dapat dilihat bahwa persentase validitas adalah $82 \%$, berada pada level validitas baik dan kualifikasi kelayakan tidak perlu revisi. Karena tingkat validitas dan kelayakan yang baik dari validator konten materi, media pembelajaran pop-up berbasis sains yang telah dikembangkan layak digunakan dan tidak diperlukan revisi.

2. Validasi desain media. Berdasarkan hasil perhitungan, dapat dilihat bahwa persentase validitas adalah 91\%, berada pada tingkat validitas yang sangat baik dan kualifikasi kelayakan tidak perlu direvisi, karena tingkat validitas dan kelayakan validator desain media adalah media pembelajaran pop-up berbasis sains yang dikembangkan. layak digunakan dan tidak perlu direvisi. 


\section{MADRASAH}

Jurnal Pendidikan dan Pembelajaran Dasar

p ISSN: 1979-5599 | e ISSN: 2502-194X

P a g e | 51

3. Validasi guru kelas. Berdasarkan hasil perhitungan rumus di atas, dapat dilihat bahwa persentase validitas adalah $90 \%$, berada pada tingkat validitas yang sangat baik dan kualifikasi kelayakan tidak perlu direvisi, karena tingkat validitas dan kelayakan yang baik validitas guru kelas adalah media pembelajaran pop-up berbasis sains. Telah dikembangkan yang sesuai untuk digunakan dan tidak perlu direvisi.

Pembelajaran di TK / RA berpusat pada anak-anak dengan memberikan kesempatan seluas mungkin untuk aktif dalam proses belajar. Aplikasi media pembelajaran pop-up berbasis sains mencakup proses mengamati dan berkomunikasi untuk melatih anak agar selalu aktif dalam belajar.

Aplikasi media pembelajaran menggunakan media pop-up memiliki manfaat tersendiri, yaitu: Mengajar menarik perhatian peserta didik sehingga dapat menumbuhkan motivasi belajar, materi ajar akan lebih jelas didefinisikan, sehingga peserta didik dapat lebih memahaminya, dan memungkinkan peserta didik untuk menguasai tujuan mengajar dengan baik, metode pembelajaran bervariasi, tidak hanya komunikasi verbal melalui kata-kata yang diucapkan instruktur, pelajar tidak bosan, dan guru tidak lelah dan pelajar melakukan lebih banyak kegiatan pembelajaran, karena tidak hanya mendengar penjelasan dari guru, tetapi juga kegiatan lain yang dilakukan seperti: mengamati, melakukan, menunjukkan dan lain-lain.

\section{E. KESIMPULAN}

Pengembangan dalam penelitian ini menghasilkan produk yang berupa media pembelajaran pop-up berbasis sains. Produk ini telah memenuhi komponen sebagai media pembelajaran dengan kriteria valid. Media pembelajaran yang dikembangkan dapat menambah keberagaman media pembelajaran dalam proses pembelajaran terutama terkait sains pada anak usia dini di kelompok B RA Raden Fatah Podorejo.

Penerapan media pembelajaran pop-up berbasis sains ini dilakukan dengan melihat keefektifan dan kemenarikan dengan membuat aktivitas pembelaajran menjadi 3 macam, yaitu dengan kegiatan awal (tanya jawab untuk mengetahui pemahaman anak tentang sains), kegiatan inti (anak diajak untuk bermain sambil belajar terkait sains dalam materi hewan ternak), dan kegiatan penutup (recalling materi yang telah disampaikan melalui media pembelajaran). Sejalan dengan hasil pengamatan, anak terlihat aktif pada saat proses pembelajaran berlangsung, anak mampu mengerjakan penugasan dengan baik dikarenakan bantuan media pembelajaran pop-up berbasis sains.

\section{REFERENCES}

Aisyah, S. (2008). Perkembangan dan konsep dasar pengembangan anak usia dini. Jakarta: Universitas Terbuka.

Alma, B. (2009). Guru profesional menguasai metode dan terampil mengajar. Bandung: Alfabeta. Budiarti, A. (2017). Pengembangan Media Pop-Up Book Pada Pembelajaran Subtema Keunikan Daerah Tempat Tinggalku Kelas IV Sekolah Dasar (other). University of Muhammadiyah Malang. Retrieved from http://eprints.umm.ac.id/35515/

Dewi, A. C. (2012). Meningkatkan Kemampuan Sains Anak Usia Dini Melalui Pembelajaran Berbasis Keterampilan Proses. Malih Peddas (Majalah Ilmiah Pendidikan Dasar), 1(2). https:// doi.org/10.26877/malihpeddas.v1i2.301

Mulyasa, E. (2007). Kurikulum tingkat satuan pendidikan sebuah panduan praktis. Bandung: PT Remaja Rosdakarya.

Padmowihardjo, S. (2014). Psikologi Belajar Mengajar. Bandung: Universitas Terbuka

Sanaky, H. A. (2009). Media pembelajaran. Yogyakarta: Safiria Insania Press 
Suprihatiningrum, J. (2013). Guru profesional: pedoman kinerja, kualifikasi E kompetensi guru. ArRuzz Media.

Ward, H. (2010). Pengajaran sains berdasarkan cara kerja otak. Terjemahan Oleh Endah Sulistyowati Dan Agus Suprapto. Jakarta, Indonesia: Indeks.

Yulianti, D. (2010). Bermain sambil belajar sains di taman kanak-kanak. Jakarta: Indeks.

Yus, A. (2011). Penilaian perkembangan belajar anak taman kanak-kanak. Jakarta: Kencana. 


\section{PANDUAN PENULISAN \\ MADRASAH: JURNAL PENDIDIKAN DAN PEMBELAJARAN DASAR \\ FAKULTAS ILMU TARBIYAH DAN KEGURUAN \\ UNIVERSITAS ISLAM NEGERI MAULANA MALIK IBRAHIM MALANG}

\section{Umum}

1. Karya ilmiah harus asli, belum pernah dipublikasikan di media lain, atau sedang dalam proses review untuk diterbitkan di publikasi lain (melampirkan surat pernyataan).

2. Menggunakan Bahasa Indonesia atau Bahasa Inggris* (*Pastikan penulisan dengan Bahasa Inggris sesuai kaidah yang berlaku, dan disubmit online melalui http://ejournal.uin-malang.ac.id/index.php/madrasah, kami tidak bertanggung jawab jika artikel anda tidak mendapat respon dari reviewer)

3. Menggunakan kertas A4 $(21 \mathrm{~cm} \times 29.7 \mathrm{~cm})$, dengan margin kiri $2.5 \mathrm{~cm}, 2 \mathrm{~cm}$ kanan, $2 \mathrm{~cm}$ bawah, $2 \mathrm{~cm}$ atas.

4. Jumlah paper minimal 6 halaman, maksimal 16 halaman kecuali ada lampiran, toleransi maksimal 20 halaman dengan 1 spasi dan alignment justify.

5. Font yang digunakan Book Antiqua 12 pt dan Sakkal Majalla (Jika ada konten Bahasa Arab) 14 pt.

6. Disarankan menggunakan referensi yang terbaru 10 tahun terakhir, kecuali kitab klasik.

7. Format file menggunakan Mic. Office/open Office (disarankan office 2013/2016_ dengan eksistensi RTF bukan PDF.

\section{Kontent Naskah}

1. Judul maksimal 15 kata, alignment center.

2. Nama penulis tidak menggunakan gelar, mencantumkan institusi, dan email.

3. Abstrak minimal $150 \mathrm{kata}$ dan maksimal $300 \mathrm{kata}$, satu paragraph, tidak terdapat tabel dan gambar.

4. Keywords minimal 3 kata dan maksimal 5 kata, dipisahkan dengan tanda titik koma $(;)$.

5. Sistematika penulisan: Judul, Abstrak, Kata Kunci, Pendahuluan, Metode, Hasil, Pembahasan, Simpulan dan Saran, Pernyataan Terima Kasih (jika ada), Daftar Rujukan. Selain hasil riset, menyesuaikan dengan format penulis.

6. Format Tabel (Bold). Jika terdapat tabel, jarak antara row adalah 1 spasi, pada kategori tabel huruf ditebalkan (bold), dan penulisan sumber setelah tabel terakhir. Jika tabel bersambung ke halaman berikut blok row kategori tabel dengan kemudiak klik layout $=>$ repeat header rows seperti format tabel A.1.

Tabel A.1 Judul Tabel (justify)

(1 spasi)

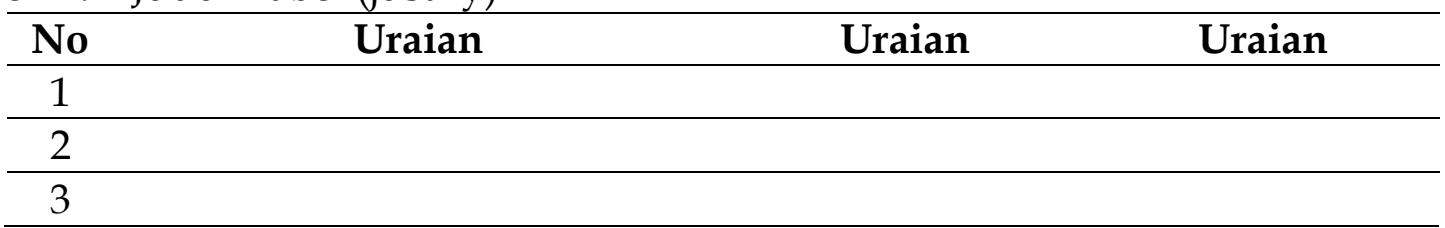

Sumber: 


\section{Format Gambar}

Jika terdapat gambar, grafik, diagram, dan yang serupa gunakan format dan wrap text gambar $=>$ in line with text atau menggunakan fitur text box, untuk kestabilan terhadap perubahan format dan pergesaran. Jarak antara kalimat terakhir dan sesudah gambar adalah 1 spasi. Gambar posisi center (tengah) seperti gambar A.1. (1 spasi)

Gambar A.1 Judul Gambar (center)

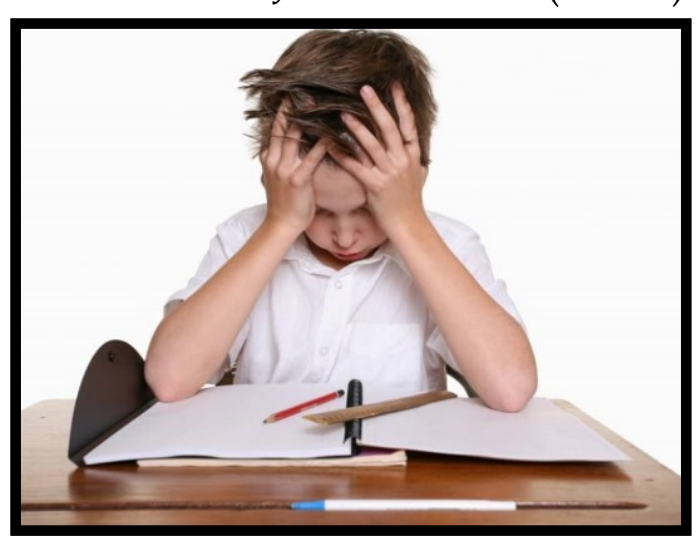

Sumber: (center)

(1 spasi)

\section{Format Numberring}

Pada jurnal Madrasah tidak diperkenankan menggunakan Bullet hanya Numberring, kecuali termasuk dalam penulisan rumus. Numbering menggunakan format Huruf dan Angka. Dimulai dari Huruf kemudian Angka seperti format berikut.

Format Numbering:

A.

1.

2.

a.

b.

1)

2)

a)

b)

B.

C.

9. Daftar Kutipan dan Rujukan menggunakan format APA 6 $^{\text {th }}$ Style Edition. Disarankan menggunakan aplikasi referensi seperti Zotero, Mandeley, Endnote, dan sebagainya.

10. Sebelum mengirim naskah, disarankan untuk melakuken cek typographical dan grammatical errors serta cek plagiat, bisa melalui.

a. Grammarly: www.grammarly.com 
b. Turnitin: http://turnitin.com/

11. Contatc:
a. Website : http://ejournal.uin-malang.ac.id/index.php/madrasah
b. Email : madrasah@uin-malang.ac.id
c. Editor in Chief: M. Irfan Islamy (085390790907)

\section{Author Fees}

This journal charges the following author fees.

Article Submission: 0 (IDR)

Fast-Track Review: 0 (IDR)

Article Publication: 0 (IDR)

Open Donations:

\section{Copyright Notice}

Madrasah: Jurnal Pendidikan dan Pembelajaran Dasar

\section{Privacy Statement}

The names and email addresses entered in this journal site will be used exclusively for the stated purposes of this journal and will not be made available for any other purpose or to any other party. 
UCAPAN TERIMAKASIH

KEPADA PARA REVIEWER, EDITOR, DAN PENULIS ATAS TERBITNYA MADRASAH: JURNAL PENDIDIKAN DAN PEMBELAJARAN DASAR VOLUME 11 NOMOR 1 DESEMBER 2018 